\title{
Ю.В. Щербинина
}

Московский педагогический государственный университет, 119991 г. Москва, Российская Федерация

\section{Зачем книге «картинки»?}

Аннотация. Статья посвящена анализу функций книжной иллюстрации в исторической ретроспективе - от Античности до современности. Рассматриваются цели и задачи включения в книгу изображений различного типа, специфика визуальной репрезентации ее содержания на основных этапах становления и развития книжного дела. Прослеживается специфика визуализации текстового наполнения книги в зависимости от ее жанра, адресата, культурного статуса в разные исторические периоды. Описываются отраслевая специализация, профессиональные подходы, творческие стратегии деятельности художников-иллюстраторов.

Ключевые слова: книжная миниатюра, иллюстрация, иллюстрированное издание, функции иллюстраций, книжная культура

\section{J.V. Shcherbinina}

Moscow Pedagogical State University, Moscow, 119991, Russian Federation

\section{Why would a book need "pictures"?}

Annotation. The article deals with the analysis of the functions of book illustration in a historical retrospect - from Antiquity to the present. The purposes and tasks of including images of various types in the book, specificity of visual representation of its contents at the main stages of forming and development of book business is considered. The specificity of visualization of the text content of the book depending on its genre, addressee, and cultural status in different historical periods is traced. Industry specialization, professional approaches, creative strategies of illustrators are described.

Keywords: book miniature, illustration, illustrated edition, functions of illustrations, book culture 